\title{
Microcirculation in obesity: an unexplored domain
}

\author{
NICOLAS WIERNSPERGER ${ }^{1,2}$, PIERRE NIVOIT ${ }^{1}$ and ELIETE BOUSKELA ${ }^{1}$ \\ ${ }^{1}$ Laboratório de Pesquisas em Microcirculação, Centro Biomédico, Universidade do Estado do Rio de Janeiro \\ Pav. Reitor Haroldo Lisboa da Cunha, Rua São Francisco Xavier, 524 \\ 20550-013 Rio de Janeiro, RJ, Brasil \\ ${ }^{2}$ INSERM UMR870, INSA Lyon, Lyon, F69008, France
}

Manuscript received on November 8, 2006; accepted for publication on June 6, 2007; presented by LUCIA MENDONÇA PREVIATO

\begin{abstract}
Obesity is traditionally linked to diabetes and cardiovascular diseases. Very recent experimental, clinical and epidemiological, sometimes provocative, data challenge this automaticity by showing that not the amount but the distribution of fat is the important determinant. Moderate abdominal fat accumulation may thus be more harmful than even consequent overweight. In view of the worldwide burden of obesity, factors leading to it in children and young adults must urgently be identified. Since obesity is a very complex cardiometabolic situation, this will require to focus investigations on uncomplicated obese subjects and adequate animal models. The recent discovery of intergenerational transmissions of obesity risk factors and also the key role played by gestational and perinatal events (epigenetic factors) give rise to completely new concepts and research avenues. Considering the potential close relationship between microcirculation and tissue metabolism, demonstrations of structural and/or functional abnormalities in microvascular physiology very early in life of subjects at risk for obesity might provide a solid basis for further investigations of such links. Microcirculation (arterioles, capillaries and venules) is conceivably a key compartment determining over one or several decades the translation of genetic and epigenetic factors into fat accumulation. Available animal models should serve to answer this cardinal question.
\end{abstract}

Key words: cardiovascular disease, diabetes mellitus, birth weight, metabolic syndrome, leptin.

\section{INTRODUCTION}

The explosion of obesity worldwide is a considerable threat for social health and related costs (Raymond et al. 2006). In Brazil its prevalence raised from 4.2 to $14.3 \%$ in a period of 1975 to 1997 (Popkin 2004), while in countries like USA this number amounts to $40 \%$.

Overweight and obesity are the soil for most cases of cardiovascular diseases and type 2 diabetes, since about $85 \%$ of diabetic patients have, at least, overweight. Appearing well before type 2 diabetes and being, in most cases, related to metabolic syndrome, obesity becomes a preferential target for future new therapies facing the

Correspondence to: Professor Eliete Bouskela E-mail: eliete_bouskela@yahoo.com.br relatively poor success rate of diet or dieting. However, as will be seen, very recent findings tend to change our views, questioning the classical (oversimplified?) view that overweight and obesity are automatically linked to increased mortality.

\section{BODY WEIGHT AND CARDIOVASCULAR DISEASES: CHANGING VIEWS?}

Persons aged 50 years or more have a $20-40 \%$ increased risk of all-cause death if overweighted and 200-300\% if obese (Adams 2006). Large vessel function is impaired independently of the age at which obesity develops: obese children have elevated cardiovascular risk at adulthood (Goodman et al. 2005, Burke 2006), even if obesity was confined to childhood (Singhal et al. 2004). 
Similarly, young obese adults already exhibit aortic stiffness (Wildman et al. 2003). However, the most important discovery in recent years, using partly retrospective studies, is the specific relationship between cardiovascular diseases and some degrees or forms of obesity. These findings, which appear homogeneous, may drastically change our views as to what to treat. Indeed two major orientations emerge from these findings:

1) the prominent importance of abdominal vs. ectopic fat accumulation;

2) the "subpopulations" of overweight/obese patients and their relative risk levels for cardiovascular diseases.

Several studies have shown the particular importance of visceral fat accumulation: men with 'hypertriglyceridemic waist' have a 20 fold increase in cardiovascular disease risk (Despres et al. 2001) and the severity of metabolic syndrome and risk for cardiovascular diseases are increasing with higher amounts of abdominal fat (Mori et al. 2006). This connection is active independently of other factors (Despres 2006). Reasons for this close association are discussed elsewhere in this review.

Very recent data show that overweight, high body mass index (BMI, relationship between weight in $\mathrm{kg}$ and height in $\mathrm{m}^{2}$ ) and obesity are general terms with obscure and subtle relationships. Kip and co-workers (Kip et al. 2004) have shown that metabolic syndrome, rather than BMI, is linked to coronary artery disease which illustrates one of the main difficulties in understanding mechanisms leading to or aggravating obesity, namely the high number of interfering factors (genetic, acquired or environmental and social) which can bias studies in such patients. Surprisingly, there are data from large scale clinical and epidemiological investigations showing that either underweighted or severely overweighted patients to be the ones at high risk for cardiovascular diseases, whereas mildly overweight and moderately obese were not (Flegal et al. 2005). A meta-analysis of 40 studies with a total of about 205.000 patients followed for 3.8 years revealed that overweight or obese patients had even a reduced risk for cardiovascular diseases, with only severely obese subjects being at increased risk (RomeroCorral et al. 2006). This challenging result is corrobo- rated by a study in 7767 patients with heart failure: while all-cause mortality was $45 \%$ in underweight patients, it was only $28 \%$ in obese patients, a number even lower than the one found for healthy subjects (Curtis et al. 2005). Another study showed that, in the absence of confounding factors such as smoking, obese patients $(\mathrm{n}=$ 22025 followed for 23 years) showed a low risk association with cardiovascular diseases (Jonsson et al. 2002).

All recent investigations identify the abdominal fat as the "bad player", thereby confirming previous observations about the determinant role of even $1 \mathrm{~kg}$ of intra-abdominal fat loss for improving insulin resistance. Abdominal fat is highly lipolytic and secretes many cytokines and inflammatory mediators responsible for peripheral insulin resistance. This effect is far less important for peripheral subcutaneous fat. Overweight and obesity therefore will have to be considered differently from before, as absolute amount of excessive weight appears less important than its body localization. Thus a few intra-abdominal kilograms of fat are much more harmful than more kilograms distributed over the whole body: as an example, subjects may develop ectopic obesity instead of abdominal one, accumulating subcutaneous fat (which is less harmful), thereby affording for a paradoxical protection (Cherian and Santoro 2006). Moreover the vast majority of type 2 diabetic patients are overweight or obese but conversely the burden of diabetes expected from the enormous number of obese individuals has not yet been observed. These new and partly provocative aspects then suggest that obesity might no longer be viewed as a general medical threat but rather give priority to properly identification of subjects presenting visceral fat accumulation, which can easily and conveniently be determined by simple waist circumference or waist/hip ratio measurements. As a consequence, therefore, the health problem caused by obesity may become more important essentially due to high and growing number of obese patients rather than because of morbidity on its own (Gibbs 2005).

\section{OBESITY: A COMPLEX STATE TO INVESTIGATE}

Obesity is a multifactorial disease, by origin (hereditary and social factors) and clinical picture: a vast majority of obese adult subjects have metabolic syndrome, being most of them insulin resistant (IR). Insulin resistance 
itself is a major threat for developing diabetes and/or cardiovascular diseases. These frequent metabolic and regulatory derangements bias the interpretation of many investigations while therapeutic concepts require more than just correlations. Ideally, therefore, studies aiming to identify mechanisms responsible for obesity should be performed either early in life in selected populations or in patients with uncomplicated obesity. Interestingly a recent estimation made in Italy, revealed that $27 \%$ of obese patients had uncomplicated obesity (Iacobellis et al. 2005), a number which looks surprisingly high. Unfortunately the medical awareness of this situation is still low and few data are available from this particular subgroup of obese patients. The existing ones show that flow-mediated dilatation (FMD), a well-accepted clinical test to investigate endothelial-dependent vascular reactivity, is reduced in uncomplicated obesity and linked to insulin resistance (Pasimeni et al. 2006). Also in these patients, body fat distribution determines endothelial dysfunction (ED) which is linked to elevated abdominal fat, whereas metabolic parameters, blood pressure and body weight did not correlate with it (Arcaro et al. 1999, Suh et al. 2005). These findings suggest that endothelial dysfunction, a predictor of coronary and peripheral arterial diseases, is possibly inherent to obesity, although the presence of insulin resistance precludes any definitive conclusions. Clearly, more clinical studies targeting uncomplicated obese patients should be encouraged.

\section{OBESITY, VASCULAR REACTIVITY, MICROCIRCULATION: WHAT IS MEASURED?}

Vascular reactivity is a prominent physiological mechanism adapting organ and local blood flow to acute and chronic tissue requirements. Vascular dysfunction, as analyzed by global or specific local techniques, not only depends on both structural and functional changes in feeding arteries but also largely on the microcirculation. In fact, microvessels are the true site of blood/tissue nutrition and exchange; accordingly they represent the largest part of vessels in the body and are subjected to multiple, fine tuning regulations.

Larger arteries are conduit vessels, mid-sized and small arteries are resistance vessels (mainly controlling blood pressure) while terminal arterioles $(<50 \mu \mathrm{m}$ diam- eter), capillaries (diameter of 5-6 $\mu \mathrm{m}$ ) organized in units, and venules represent the microvascular bed. Precapillary arterioles feed capillary units formed by about 15 capillaries each and finely regulate the qualitative and quantitative aspects of blood flow through these units. This regulation is ensured by completely specific, essentially local nervous and humoral control systems aimed at adapting, in the most economical manner, the blood flow to local metabolic requirements of surrounding tissue.

Global investigations of vascular function, although comprising the microcirculation, also encompass large and mid-sized vessels in classical tests such as reactive hyperemia to transient ischemia. However, mechanisms underlying physiological regulation of these consecutive vessel segments strongly differ, not only along the vascular tree but also from organ to organ. Therefore the relevance of findings obtained in "in-between" studies is questionable, depending on evaluation of the technique used (ex: venous plethysmography vs. ultrasound) and which tissue is investigated (ex: whole limb vs. skeletal muscle vs. skin).

\section{ENDOTHELIAL DYSFUNCTION}

Nitric oxide (NO), considered the main mediator of flow-mediated dilatation, appears to be more representative of large and small arteries than of terminal arterioles (Pohl et al. 2000). Moreover, while the reactive hyperemia is largely due to NO in skeletal muscle, this is different in the skin (Wong et al. 2003, Hansell et al. 2004). Finally the reactive hyperemia response following ischemia of short duration is mainly linked to NO but longer ischemic episodes call for additional mechanisms such as prostaglandins or factors involved in nervous system control of vessels. Altogether flowmediated dilatation, the most widely used technique in clinical studies, has thus a limited relevance and provides essentially valuable information when measurements originate from "within-patient" studies. These differences explain the discrepancy seen in published reports. Recent analyzes showed that flow-mediated dilatation in forearm correlated well with arterial stiffness in other organs (Mitchell et al. 2005), but the extent it represents macro $v s$. microcirculation is a matter of debate (Shamim-Uzzaman et al. 2002, Minson and Wong 2004, 
Silber et al. 2005). Flow-mediated dilatation potentially also results from non-endothelial dilating mechanisms operating in smooth muscle cells; however, since most studies fail to show abnormalities in this part of the vessel wall, flow-mediated dilatation is considered to represent essentially endothelial function. However, because the reactive hyperemia response following an ischemic episode is undoubtedly linked, to a significant extent, to the microcirculation, one should review existing data on endothelial dysfunction in obese subjects.

Abnormalities in flow-mediated dilatation, representing endothelium dysfunction, are linked to obesity independently of hypertension, although most obese patients have at last mild elevations in blood pressure (Higashi et al. 2001). Endothelial dysfunction has been found in most dedicated studies and again fat distribution has been found to be the main determinant (Hashimoto et al. 1998, Nestel et al. 1998, Suh et al. 2005). Thus waist/hip ratio, a clinical marker representing abdominal obesity, seemed to be better correlated with endothelial dysfunction than BMI (Brook et al. 2001, Villela et al. 2006, Weinbrenner et al. 2006). Other methods use intrabrachial acetylcholine injections (Lind et al. 2002) to induce vasodilatation by other mechanisms than shear stress induced by hyperemia: they confirm a reduction in vasodilating capacity, even in normotensive/normoglycemic obese patients (Van Guilder et al. 2006). Alternatively, local insulin injections can be used to induce NO-mediated dilatation to further confirm prevailing endothelial dysfunction (Westerbacka et al. 1999). Interestingly, when overweight, hypertriglyceridemic patients were put on diet, prominent cardiovascular risk factors such as PAI-1 or ICAM-1 were reduced without any significant improvement on flow-mediated dilatation (Clifton et al. 2005).

In addition to diminished vasodilatation, increased vasoconstriction can also occur, which may partly explain blunted dilatatory reactions and give rise to false interpretations about defective mechanisms. In patients with upper body obesity, no endothelial dysfunction but enhanced constriction to angiotensin II was reported (Nielsen et al. 2004). Elevated vasoconstriction may thus blunt vasodilatation in specific tests, possibly giving misleading informations. For example, increased en- dothelin levels were shown to mask a normal NO production (Mather et al. 2004, Stepp 2006).

\section{Microcirculation: Technical and Mechanistic SPECIFICITIES}

Physiology, biochemistry and pharmacology vary according to vessels size and location. However, the compartment for tissue nutrient delivery, which ultimately determines cell life, is the microcirculation. The correlation between flow-mediated dilatation and microcirculatory variables is a matter of debate (Shamim-Uzzaman et al. 2002, Hansell et al. 2004): in the same animal, aortic vasodilatation was normal while small vessels exhibited endothelial dysfunction (Stepp 2006) but another recent study did not find any dysfunction in skin of obese patients, in contrast to what occurs in skeletal muscle (Seywert et al. 2004). Considering that flow-mediated dilatation does neither entirely nor necessarily represent the microcirculation, direct microcirculatory measurements must also be performed in order to obtain more specifically relevant data for mechanistic interpretations.

The microcirculation can be analyzed non-invasively in humans either by direct intravital capillaroscopy on skin or nailfold, or by laser Doppler measurements. In animal research, these techniques can be used in relevant organs such as skeletal muscle, hamster cheek pouch or mesenterium. Studies in muscle are particularly important in view of the suspected cardinal role of the microcirculation in insulin resistance/ metabolic syndrome.

Animal studies have mainly been performed in obese Zucker rats. Both structural and functional defects are present in the microcirculation of these animals: microvessel permeability to macromolecules is increased (St-Pierre et al. 2006) and capillary rarefaction well documented, independently of prevailing hypertension (Frisbee 2005). Baseline arteriolar diameter was dec reased in a muscle preparation (Frisbee 2003) and sympathetic nervous system activated in these rats (Alvarez et al. 2002) but not subcutaneous fat (Alvarez et al. 2004). Due to elevated adrenergic tone and to structural vessel narrowing, the reactive hyperemia response was impaired (Frisbee 2006). Capillary rarefaction in skeletal muscle was also found in all fibre types in obese patients (Gavin et al. 2005). Already in normal children, skin microvascular response to acetylcholine is negatively correlated with central adiposity (Khan et al. 
2003). Obese children exhibited increased basal cutaneous blood flow but peak capillary blood cell velocity was reduced during the reactive hyperemia response, a finding obviously unrelated to the subject's dyslipidemia (Chin et al. 1999). Dilatation to other stimuli affecting the microcirculation was also defective: despite similar increases in blood pressure, responses in skeletal muscle or skin to mental stress were impaired (Agapitov et al. 2002). Peripheral vasodilatation following an oral glucose load was blunted in obese patients (Baron et al. 1990), probably due to absence of capillary recruitment to plasma insulin increase in these subjects (DeJongh et al. 2004a, Clerk et al. 2006). Not only insulin-induced vasodilatation but also insulin passage from blood to tissue may limit hormonal action since in obesity, transendothelial insulin transport was reduced (Sjostand et al. 2005, Wascher et al. 2000). In smaller arterioles, vasodilatation is more dependent on EDHF (endothelial-derived hyperpolarizing factor) family mediators than on NO. Although the exact nature of $\mathrm{EDHF}(\mathrm{s})$ is obscure, impaired vasodilatation was linked to reduced response of inwardly rectifying potassium channels in humans with visceral obesity (Vigili de Kreutzenberg et al. 2003).

Microvascular blood flow depends on capillary density, which itself depends on muscle fibre type. Oxidative fibres, requiring more energy consumption, have smaller iameter and are surrounded by more capillaries/fibre than non-oxidative or intermediate fibres. This kind of bias could potentially explain apparent differences in endothelial function between muscle and skin (Seywert et al. 2004). Therefore, functional capillary studies in muscle should ideally be accompanied by histochemical determination of fibre type and capillary counting. Data on muscle fibre type composition in obesity are scarce: an increase of type IIb at the expense of type I fibres has been reported (Kriketos et al. 1996) but other obscure mechanisms may operate: after diet, capillary density was increased by $54 \%$ whereas muscle fibre type was unchanged (Kern et al. 1999). Clearly, more investigations in this field would be worthwhile.

\section{HEMORHEOLOGY}

Regulation of large and small vessels is partly operated through sensing mechanic forces applied by flowing blood on vessel walls (shear rate, shear stress). Blood flow behaviour is highly dependent on plasma viscosity and blood cell fluidity/stickness. Elevated plasma viscosity is indeed a hallmark of obesity (Cortinovis et al. 1997, Hernandez et al. 2002), possibly due to the abnormal lipid profile, present in most of these patients (Aloulou et al. 2006). Whole blood and plasma viscosity predict intima/media thickness in arteries (Zhu et al. 2005) and, interestingly, both parameters are closely linked to decreased peripheral glucose uptake even in normal subjects (Moan et al. 1994). The latter observation supports a role for microcirculation having a causative implication in metabolic syndrome. Erythrocyte deformability is reduced in obesity, potentially hampering flow passage through the capillary bed (Cortinovis et al. 1997). Triglycerides aggregate red cells, which leads to inhomogeneous flow within the capillary network (Maeda et al. 2006).

In conclusion, animal and human studies clearly document highly significant defects in vascular reactivity in all vascular segments. This is particularly relevant for visceral obesity. At the microcirculatory level, both structural and functional defects are observed which combined to hemorheological abnormalities, make impaired microflow likely. Finally one should remember that microcirculation is an integral, sometimes cardinal, part of large vessel diseases (Schwitter et al. 2006).

\section{MECHANISMS INVOLVED IN MICROCIRCULATORY DISTURBANCES IN OBESITY}

Established obesity is a multifactorial pathological situation, encompassing dyslipidemia, hypertension and usually most of the components of insulin resistance and metabolic syndrome. It is thus difficult to discriminate what is really responsible for the defective vascular reaction in obesity. Again, uncomplicated obesity could provide better answers but such data are missing today. If we consider abdominal obesity and the early installation of peripheral insulin resistance, one might suggest that the crosstalk between intra-abdominal fat and skeletal muscle provides some interesting clues.

\section{Circulating Mediators}

The last decade has largely established that metabolic syndrome and frequent accumulation of fat in abdomi- 
nal tissues are accompanied by an inflammatory state: elevated levels of CRP, PAI-1, TNF $\alpha$, IL-6 and changes in adipokines, produced by fat cells (particularly adiponectin). Several of these mediators are indeed known to produce vascular effects similar to those observed in obesity.

Without detailing this field here, one should nevertheless recall that PAI-1 plays a prominent role in both metabolic and vascular abnormalities linked to metabolic syndrome (Griffiths and Grainger 2006). PAI-1 is produced by visceral fat, in contrast to subcutaneous fat (Shimomura et al. 1996). Mice lacking PAI-1 have higher basal metabolic rate and do not develop obesity on a high fat diet (Ma et al. 2004). Similar findings are observed when PAI-1 is pharmacologically inhibited (Crandall et al. 2006).

In addition to interfering directly with the insulin receptor, TNF $\alpha$ blocks capillary recruitment to insulin, which can cause a decrease of glucose uptake in skeletal muscle fibres and peripheral insulin resistance (Youd et al. 2000, Ijzerman et al. 2006). Interleukin-6, on the other hand, is atherogenic, stimulates the hypothalamohypophyseal axis favouring obesity and blunts NO-induced vasodilatation (Yudkin et al. 2000, Orshal and Khalil 2004).

Finally it was recently found that fat cells secrete ESM-1 (endothelial cell specific molecule 1), which decreases leukocyte adhesion to vessels and their transendothelial migration (Janke et al. 2006). The level of this substance is reduced in obesity and by insulin and cortisol. Potentially, therefore, low ESM-1 levels might favour leukocyte activation and oxidative stress.

The past decade has shown the cardinal importance of several adipokines secreted by fat cells, in particular the key role played by adiponectin on metabolic and cardiovascular regulation (Ouchi et al. 2006). In obese subjects, particularly ones with visceral fat accumulation, adiponectin levels were decreased (Kim et al. 2006). Low postnatal adiponectin levels correlated inversely with weight gain in children born small for age (Iniguez et al. 2004).

Dyslipidemia is a common feature in obesity. Free fatty acids can block capillary recruitment (De Jongh et al. 2004b, Clerk 2002) and high fat diet leads to both capillary rarefaction and insulin resistance (Kemppainen et al. 2003, Nusz et al. 2003). Presently it is accepted that very early fat deposition in muscle cells is a hallmark of prediabetic insulin resistance (Malenfant et al. 2001). Some findings suggest that microcirculatory defects, deriving blood supply from nutritive vascular channels, could also explain the intermyofibrillar fat deposition in skeletal muscles (Clerk et al. 2000). An elegant hypothesis has recently been proposed, stating that periarteriolar fat, like abdominal fat, might liberate TNF $\alpha$ and thereby block local NO production or sensing ("vasocrine" fat signalling) (Yudkin et al. 2005).

\section{From CAPILlary Flow to Insulin Resistance}

Insulin resistance is usually- but not automatically accompanying obesity. There is little doubt that each of both interact, creating a vicious circle constantly aggravating the metabolic situation. Since microvascular defects can be observed even shortly after birth in subjects at risk for metabolic syndrome (Wiernsperger et al. 2007), the concept of microvascular disturbances being a primary event leading to insulin resistance has to be addressed. Several recent dedicated reviews on this - yet to be proven- hypothesis can be found (Tooke and Goh 1998, Wiernsperger 2000, Hayden and Tyagi 2003, Tudor et al. 2005, Matsumoto et al. 2006). One may just mention here that it makes sense that limited capillary perfusion, whether due to defective recruitment or structural density, subsequently limits the supply of glucose and insulin in skeletal muscle cells, thereby favouring insulin resistance (Wiernsperger et al. 2007). Indeed it was shown that even in normal individuals, capillary density and insulin sensitivity were correlated (Lillioja et al. 1987, Marin et al. 1994). It is of interest that a reduction in muscle capillary density was observed following myocardial infarction or heart failure (Kindig et al. 1999, Nusz et al. 2003), two patient populations likely to develop insulin resistance or even diabetes within a couple of years (Pajunen et al. 2005). Finally there is still a debate as to whether anteceding capillary rarefaction, as seen in offsprings of hypertensive parents, might be responsible for the later development of hypertension in adulthood (Antonios et al. 2003).

All these data point to a potentially important and causative role of microcirculation at early steps of metabolic diseases. Obesity is linked with an array of circu- 
lating and nervous factors expected to impair microflow, potentially resulting in generation or aggravation of metabolic and cardiovascular disturbances. The potential bidirectional link between microcirculation and insulin resistance (Wiernsperger et al. 2006), however, also raises the question of a causal role of microvascular derangements upstream of overweight/obesity. Therefore, studies in very early states in life of at risk patients would be helpful to answer this important question.

\section{OBESITY: SHOULD WE LOOK BACK?}

Investigating the microcirculation in animals or patients prone to develop obesity would (1) reduce the bias represented by very abnormal and complex changes in the metabolic and hormonal milieu encountered in established obesity and (2) allow to identify eventual initial disturbances in microcirculation which could favour the development of it.

\section{ON ORIGINS OF OBESITY}

The burden of infant overweight and childhood obesity in westernalized and developing countries has contributed to consider more closely the origins of obesity. It might be inherited, acquired or programmed. During recent years, challenging data have been provided to answer these cardinal questions.

That obesity can be inherited is self-evidence. It is less recognized, however, that offsprings of parents presenting hyperdynamic circulation (top cardiac index tertile) frequently present elevated BMI, waist/hip ratio and diastolic blood pressure (Palatini et al. 1999) as well as high triglycerides (Stern et al. 1992) or thickened subscapular skinfold even as children (Jiang et al. 1995). This type of finding supports the notion that hemodynamic disturbances have probably set a genetic imprinting translating into metabolic abnormalities.

A major new notion is the accumulating evidence for intergenerational transmission of metabolic syndrome or obesity. It is thus fascinating to note that birth weight, a very important factor as will be seen later, relates to diabetes in grandparents in a U-shaped curve (McCarron et al. 2004.). Intrauterine growth retardation (IUGR) due to low protein diet during gestation is linked to intergenerational consequences as expressed by "small for gestational age (SGA)" babies (Drake and
Walker 2004, Selling et al. 2006). The same is seen with elevated glucocorticoid levels in utero (Drake et al. 2005). Very recent data confirm these findings by showing that it extends at least to F3 generation: these pups are intolerant to glucose if males and have fasting hyperglycemia if females. There seems to be a slow resolution in this transmission if F2 generation is put on a regular diet (Benyshek et al. 2006). Unfortunately, this is presently not the trend in humans! These exciting data demonstrate that obesity can be programmed, i.e. we might develop diseases due to environmental factors having occurred in one or more upstream generation. This also sets the limits of our comprehension because we usually ignore the anthropometric or life habits characteristics of our ancestors. As a whole we might say that, by definition, investigations are largely biased in obese patients due to the complexity of present metabolic situation and unknown factors inherited either during pregnancy or even long before.

\section{Perinatal Physiology and Obesity}

Intensive animal, clinical and epidemiological research over the recent years has shown that both pre-and postdelivery periods are crucial for the development of metabolic and cardiovascular diseases during childhood or adulthood. Interestingly, critical windows are not a matter of weeks or months but usually days! The last week of gestation as well as the first two weeks postpartum are indeed essential for some maturation processes, in particular in the central nervous system and pancreas. The awareness about possible fetal programming of obesity and/or cardiovascular diseases came from the observation that low birth weight (LBW) subjects were at high risk for developing these diseases (Remacle et al. 2004, Louey and Thornburg 2005, Hofman and Cutfield 2006). Low birth weight can be of genetic origin since it relates to parent's cardiovascular mortality (Smith et al. 2005) as well as to intrauterine growth retardation.

\section{Birth Weight and Cardiovascular Diseases}

Low birth weight individuals develop increased blood pressure and uric acid in late childhood (Irving et al. 2004, Franco et al. 2006) as well as hypertriglyceridemia and fasting hyperglycemia (Eriksson et al. 2004, Frontini et al. 2004). These findings are not universal since a 
retrospective analysis of 855 children aged 11-13 years found no global association of low birth weight with cardiovascular risk factors, whereas BMI did correlate (Daly et al. 2005). A plausible explanation for this discrepancy may be found in the prominent role, as will be seen, played by rapid initial and even delayed postnatal weight gain (Eriksson et al. 2004). One study indeed found that augmented cardiovascular diseases were restricted to low birth weight subjects who presented high BMI in adulthood (Frankel et al. 1996). A broad study performed in almost 150.000 boys aged 18 years showed also preferential blood pressure increase in low birth weight subjects having experienced postnatal catchup growth (CUG) (Nilsson et al. 1997). Carotid intima/media thickness was increased in subjects with this type of growth (Oren et al. 2004). Young, fit low birth weight adults showed reduced endothelial function, while endothelium-independent function was intact (Goodfellow et al. 1998, Leeson et al. 2001b). Children aged 8-13 years have endothelium dysfunction, linked to elevated uric acid levels (Franco et al. 2006). Other investigators did not find endothelium dysfunction but an increase in plasma von Willebrand factor as a sign of endothelial lesion (McAllister et al. 1999).

Very interestingly vascular defects are found very early in life in low birth weight subjects: while 9 years young children had endothelial dysfunction and a trend toward carotid stiffness (Martin et al. 2000a), 3 months infants showed limited maximal hyperemia (Goh et al. 2001). 1-3 months babies born low birth weight had elevated sympathetic tone and reduced activity of the autonomic nervous system (Galland et al. 2006). A study performed 3 days after delivery in low birth weight babies showed reduced dilatation to acetylcholine but not to heating (Martin et al. 2000b), which could suggest a defect in mid-sized rather than smallest arteries. All these studies suggest that microvascular defects are present from the beginning of life. Further studies will be necessary to unravel underlying mechanisms, since there is discrepancy as to a reduction - or not - in capillary density (Goh et al. 2001, Irving et al. 2004). In low-protein diet intrauterine growth retardation studies, capillary density was normal at delivery but decreased thereafter, lending support to the prominent role of postnatal environmental adaptation (Pladys et al. 2005). Capillary recruitment is reduced in low birth weight (Ijzerman et al. 2002) and relates to body weight even in healthy individuals (Serne et al. 2000). Finally it should be stressed out that, with the progressive rise in knowledge, low birth weight as such is not the real culprit: when small for gestational age subjects are compared with low birth weight preterm ones, only small for gestational age have blunted NOdependent responses (Norman and Martin 2003). This difference could explain the absence of defects in endothelial function in low birth weight populations (Hermann et al. 2003). In fact, some authors question the link between low birth weight and cardiovascular diseases (Jones and Nyengaard 1998). Nowadays small for gestational age seems therefore a more appropriate subpopulation than low birth weight when it is intended to study these topics.

\section{Birth Weight, OVERWEIGHT AND OBESITY}

Birth weight and metabolic/anthropometric data are numerous and look rather homogeneous. The reader is referred to several very complete reviews on this topic (Cianfarani et al. 1999, Gluckman and Hanson 2004, Newsome et al. 2003, Levy-Marchal and Czernikov 2006, Ong 2006). Both low and high birth weight can lead to overweight in adulthood but whereas the former is due to fat accumulation the latter is due to augmented lean mass (Ong 2006). The ARYA study has documented that low birth weight predicts metabolic syndrome, linked with hypertension and hypertriglyceridemia with an odd ratio of 1.8 (Ramadhani et al. 2006). Young adults with normal weight but born with low weight had mild hyperglycemia, were glucose intolerant and had slightly elevated blood pressure as well as higher plasma cortisol (Levitt et al. 2000). Low birth weight, thinness at 2 years and increased BMI after it lead to insulin resistance (Barker 2005). Prepubertal children born small for gestational age had reduced insulin sensitivity (Veening et al. 2004). Already at 1 year of age, infants born small for gestational age have elevated triglyceride and insulin levels (Soto et al. 2003). At any age between 2 and 47 months, small for gestational age children have more fat (Hediger et al. 1998). It has been suggested that moderate elevation in insulin levels seen in low birth weight children was due to intrauterine growth retardation rather than to low birth 
weight itself (Mericq 2006).

Peripheral insulin resistance in small for gestational age individuals is a common finding; although the precise mechanisms must be identified, since clamp studies revealed a defect but the reaction to an oral glucose tolerance test was normal (Veening et al. 2002). Very few mechanistic data are available, but it was found that modifications typical of insulin resistance at cellular level (reduced PKC activity, GLUT-4 translocation and p85 activation) occurred in low birth weight individuals (Ozanne and Hales 2005). Another hypothesis could be an augmented passage of glucocorticoids from mother to foetus, programming an increased response of the central nervous system to stress and an increased sensitivity to glucocorticoids in fat cells (Achard et al. 2006). Epigenetic programming has been reviewed recently (Holness and Sugden 2006).

Some authors suggested that not body weight but rather body length (postnatal body growth) might be the most relevant indicator of growth: small for gestational age subjects with adult short stature exhibit elevated sympathetic activity, a likely link to metabolic syndrome (Boguszewski et al. 2004).

In order to distinguish between genetically determined, inherited factors and fetal programming leading to low birth weight, some studies have elegantly approached the problem by studying twin populations. These individuals not only have the same genetic background but also have reduced birth weight. One study found that, as adults, low birth weight twins had no augmented risk for metabolic syndrome/diabetes, suggesting also here that low birth weight per se is not harmful (Tuya et al. 2003). Other studies showed increased risk for abdominal obesity in low birth weight/small for gestational age twins (Hng et al. 2006, Vaag et al. 2006). Intrapair differences in adiponectin levels and endothelial function were reported in young adult, homozygotic twins: this acquired reduction in adiponectin correlated with endothelial dysfunction rather than with obesity (Pietilainen et al. 2006). It must also be mentioned that a study performed in 50-70 years old low birth weight subjects found a link to truncal (android type) obesity but not abdominal one (Byberg et al. 2000). This type of investigation would greatly help to understand points which are still obscure due to missing data.
In conclusion, low birth weight as a global term is clearly associated with elevated risks for overweight/ obesity and cardiovascular complications, even at a young age. Clearly, the very last week of gestation is of paramount importance, although caution is recommended because rodents differ from higher mammals or humans in their degree or organ maturation at birth. These and some more specific findings, however, also point to the importance of very early postnatal environmental and nutritional factors.

\section{Postnatal Weight Gain: the Key Event?}

The studies described above clearly demonstrate that the perinatal period can be a key determinant of adult chronic diseases (Hoet et al. 2000). Since low birth weight can have different origins and is frequently related to problems linked with maternal hemodynamic or hormonal factors, other studies have focused on immediate or early postnatal period.

Indeed it was observed that if poor fetal growth was followed by accelerated postnatal weight gain (so-called "catch-up growth"), fat mass accumulation was more prominent (Ong 2006), resulting in overweight (Stettler et al. 2005) and metabolic syndrome (Fagerberg et al. 2004) in adulthood. An elegant study showed that dams subjected to $50 \%$ restriction in food intake during the last week of gestation delivered low birth weight pups, which experienced catch-up growth after birth. These animals became intolerant to glucose and obese at 6 months. When low birth weight was not followed by catch-up growth, however, animals behaved like controls (Jimenez-Chillaron et al. 2006). These findings nicely illustrate the prominent role played by catch-up growth after birth. Sheeps with low birth weight and catch-up growth after birth exhibited increases in both lean and fat mass when adult, but abdominal fat mass had the largest increment (Louey et al. 2005). Animals subjected to intrauterine growth retardation are born with low birth weight and, due to catch-up growth after birth, recover normal weight within 7 weeks: then weight gain progresses more than in control animals and, at 26 weeks, they present all signs of metabolic syndrome: hyperglycemia, intolerance to glucose, insulin resistance and loss of pancreatic $\beta$-cell mass (Simmons et al. 2001). In small for gestational age subjects, imme- 
diate postpartum insulin sensitivity was rather increased but rapidly declined within 3 days, relating to postnatal weight gain (Mericq et al. 2005). That catch-up growth leads to insulin resistance is also illustrated by a link with polycystic ovary syndrome (DeZegher and Ibanez 2006). Experimentally this combination even led to premature death in mice (Ozanne and Hales 2005). Studies showed that postnatal weight gain was the most important determinant of BMI in 7 years young children (Kinra et al. 2005).

Although the first days following delivery are crucial, catch-up growth over the first 2 years can also lead to these metabolic derangements; it was even suggested that delayed catch-up growth (weight gain between 1st and 2nd years) was more important than the early one for determining adult BMI (Ezzahir et al. 2005). Here again some authors proposed that linear body growth rather than accelerated weight gain might determine adiposity in growth- retarded infants (Modi et al. 2006).

On the vascular side, few data related to catch-up growth are available; however a $4 \%$ reduction in flowmediated dilatation was documented, which corresponds to the quantitative effects of smoking on this parameter (Singhal et al. 2004). Another study showed that those individuals with the earliest catch-up growth (between 1 and 5 years of age) had the highest blood pressure as young adults (Law et al. 2002). The reader is referred to some pertinent reviews on health problems linked to catch-up growth (Lucas 1998, Cianfarani et al. 1999, Kayes and Hindmarsh 2006, Singhal 2006).

Mechanistically the link between catch-up growth and adult diseases may be due to decreased thermogenesis. Experimental suppression of thermogenesis induced by semistarvation and isocaloric refeeding leads to catch-up growth, a decrease in skeletal muscle sensitivity to insulin and a concomitant increase in fat with high activity of the fatty acid synthase in adipose tissue (Cettour-Rose et al. 2005, Dulloo 2006). This might be mediated by $\beta_{3}$-adrenoceptors in the neonatal period (Yeung 2006). Cafeteria-diet during gestation and prolonged during lactation leads to reduced muscle mass, a potential cause of insulin resistance, since muscle is the main storage site for glucose. In fact, muscle fibre fat content was increased and fat pads were hypertrophied (Bayol et al. 2005).
Therefore we are facing a major discovery, which might explain a considerable number of cases of human obesity: gestation (especially the latest period) and early postnatal life may have programmed childhood and adulthood weight increase. This revolutionary view has prompted corresponding studies in order to understand the reasons of this phenomenon. While late gestation epigenetic imprinting can be related to the maternal health state (low protein diet, hypertension, elevated glucocorticoids, etc.), postnatal events do likely relate to (over) feeding. Indeed it is known that fat-rich diet during suckling can lead to elevated blood pressure, endothelial dysfunction and hyperinsulinemia (Khan et al. 2005) and that postnatal saturated fat intake (rather than fat intake as such) is linked to metabolic syndrome (Armitage et al. 2005, Kalies et al. 2005). This suggests that overfeeding, either in qualitative (saturated fats) or quantitative terms may exert harmful effects during the first weeks of life, which programmes later development of chronic diseases. Researchers have appropriately addressed these questions by comparing breastfeeding with formula milk feeding and by developing models to induce overfeeding.

\section{Postnatal Feeding: Quality and Quantity}

Milk formulas and infant foods are frequently rich in linoleic acid, whereby prostacyclin levels and signalling might promote and induce adipose tissue development (Massiera et al. 2003). In fact, feeding humans during the first week with milk formulas correlated with overweight/obesity (Stettler et al. 2005). Accelerated weight gain and growth were seen already at 1 year (Oddy et al. 2006). When breast feeding (BF) was combined with complementary formula foods, however, there was no difference in adiposity at age 5 years (Burdette et al. 2006), suggesting that breast-feeding might refrain growth acceleration (Singhal 2006). In fact, prolonged breast-feeding diminished the risk of overweight (Grummer-Strawn and Mei 2004) and type 2 diabetes (Plagemann and Harder 2005). However, if the mother was diabetic breast-feeding increased the risks due to modifications in milk composition. Several meta-analysis have been performed to try to give a definitive answer to this vividly debated topic: it was shown that duration of breast feeding was inversely related to the risk of becoming overweight (Harder et al. 2005) but cor- 
rection for confounding factors reduced the correlative strength (Nelson et al. 2005, Owen et al. 2005). A third meta-analysis cautiously concluded that there were no differences between breast and bottle feeding for the development of cardiovascular diseases, but pointed to the weakness of this conclusion (Marin et al. 1994). Thus, although the dominant impression is in favour of breastfeeding, a definitive conclusion is not available. On the other hand, breast-feeding might also become harmful if prolonged: one study showed reduced arterial distensibility in young adults who were breastfed for more than 4 months (Leeson et al. 2001a).

Overfeeding is another potential way to ingest excessive lipids. In a series of elegant and carefully designed experimental setups, Plagemann and co-workers (Plagemann 2006) have addressed this question by reevaluating a model where the number of suckling pups is varied in the litter (McCance 1962). Offsprings rats raised in small litters showed elevated insulin levels at day 15 after birth and higher body weight gain during the suckling period as well as increased blood pressure (Plagemann et al. 1992). Their susceptibility to the diabetogenic drug streptozotocin was increased, which is reminiscent of what is seen in adult rats fed fructose (N. Wiernsperger, unpublished results). Moreover 11BHSD1 was increased in fat, which represents a potential link to cardiovascular disturbances (Morris et al. 2005). Rats grown in small litters after birth are heavier at 40 and 80 days after birth and exhibit more epididymal and retroperitoneal fat (Mozes et al. 2004). Such animals have greatly increased visceral fat, glucocorticoid signalling and a moderate increase in corticosterone levels (Boullu-Ciocca et al. 2005). Thus this model, which concentrates on immediate postnatal period apparently exactly mimicks what is known from other experimental and clinical observations. However, also here potential differences between rodents and humans should be taken into consideration, due to differences in perinatal organ maturation. Nevertheless this "simple" model should be subjected to prioritizing investigations because it is unbiased by prenatal and hereditary influences and would allow to follow-up the development of obesity and cardiovascular disturbances over time as well as over generations. It also represents a unique situation to study the potential implication of the microcirculation as a cause of delayed development of these diseases.

\section{A Particular Role For Leptin?}

This hormone has attracted much interest during the past decade. Leptin concentration is increased in obesity and its link to appetite saturation was hypothesized. Since leptin has also clear-cut effects on the vascular system, this hormone represented an exquisite candidate to explain the genesis of obesity and cardiovascular diseases (Singhal 2005). Leptin is atherogenic and exerts many negative cardiovascular effects such as endothelial dysfunction, oxidative stress, stimulation of inflammation and platelet aggregation as well as hypertrophy or proliferation of smooth muscle cells (Beltowski 2006). $\mathrm{Ob} / \mathrm{ob}$ mice, which lack the leptin gene, are protected against atherosclerosis and, conversely, administration of leptin to such mice produces atherosclerotic lesions (Konstantinides et al. 2001). Leptin also activates the sympathetic nervous system, acting on cardiac and vascular contractility (Ren 2004). At levels found in obesity, but not at normal concentrations, leptin reduces coronary NO-dependent vasodilatation (Knudson et al. 2005). At the microcirculatory level, similar to adiponectin, leptin enhances dilatation to heat (Tigno et al. 2003). In the general population leptin independently correlates with waist/hip ratio, insulin resistance, IL-6, C-reactive protein, triglycerides, plasma viscosity, fibrinogen, von Willebrand factor and tPA but not with glycemia, cholesterol or blood pressure (Wannamethee et al. 2006). Leptin might promote lipotoxicity in skeletal muscle and pancreatic $\beta$-cells, thereby leading to insulin resistance and subsequently to cardiovascular modifications (Mark et al. 2004). However, not all studies agree about the role of leptin in the linkage between obesity and cardiovascular disease risk markers (Gomez-Ambrosi et al. 2006) or endothelial function (Rahmouni and Haynes 2005).

Concerning the perinatal period, data available look complex. It was proposed that, due to leptin- or insulinresistance, leptin concentrations would increase weight gain. Mice subjected to intrauterine growth retardation during gestation showed a postnatal leptin increase and normal mice given leptin postnatally exhibited accelerated weight gain (Yura et al. 2005). Postnatal overfed rats became resistant to leptin and exhibited a 7-fold increase in plasma leptin levels. However hyperleptinemia was not totally responsible for the resistance to the hormone (Schmidt et al. 2001). Very young obese children 
have increased leptin in the blood, less adiponectin and elevated C-reactive protein (Valle et al. 2005). Breastfed children have lower leptin levels than those fed with milk formula (Singhal et al. 2002). These data are reminiscent of what was described in previous paragraphs and suggest that higher leptin after birth might promote overweight/obesity and cardiovascular disturbances. During pregnancy leptin is also involved in growth: small for gestational age children have reduced leptin in the umbilical cord blood (Martinez-Cordero et al. 2006). In animals submitted to intrauterine growth retardation and postnatal high fat diet, leptin administration during both pregnancy and lactation prevented obesity and insulin resistance, an effect, which might be explained by an inhibition of suppression of 11B-HSD2 (Stocker et al. 2005). Another study showed that leptin administration from day 3-13 after birth slowed down the weight gain and normalized caloric intake (Vickers et al. 2005). Another approach used intracerebroventricular injection of adenovirus encoding for the leptin gene in adult female rats: these dams produced normal numbers of pups with lower weight during gestation and lactation. Their offsprings had reduced body weight, and this effect was sustained for 3 months, showing an imprinting phenomenon (Lecklin et al. 2005).

As a whole it appears that there is evidence for an implication of leptin in critical perinatal events. However data presently available are partly contradictory and it seems that pre-and postnatal leptin might have different - if not opposing - effects. Clearly further studies are needed to define its real importance.

\section{CONCLUSION}

Recent experimental, clinical and epidemiological investigations have delivered completely new insights into obesity, both on its origins and its relations to diabetes and cardiovascular diseases. To a large extent these new data challenge classical concepts about a "simple" relation of overweight with these diseases, allowing to predict that in a hopefully near future obesity will be considered in practice very differently from today. Access to well-documented patient's dossiers will favour integration of genetic as well as epigenetic aspects in order to evaluate more precisely true risks, when data such as family history (intergenerational transmission) or gestational and perinatal events will be available. It is likely that not body weight per se but fat distribution centering on the presence of even modest abdominal obesity will become the main criterion for differential diagnosis and new targeted treatments.

The role played by the microcirculation in the evolution towards obesity from early life to childhood and adulthood is still largely hypothetical. However physiological investigations about the connexion between this part of the circulation and metabolic events in surrounding tissues on one hand, availability of elegant experimental models nicely mimicking human situation in early life on the other hand, represent a solid basis for identifying to which extent the microcirculation is causally involved.

\section{ACKNOWLEDGMENTS}

This work was supported by grants from the Conselho Nacional de Desenvolvimento Científico e Tecnológico (CNPq) and Fundação Carlos Chagas Filho de Amparo à Pesquisa do Estado do Rio de Janeiro (FAPERJ).

\section{RESUMO}

A obesidade é tradicionalmente associada ao diabetes e a doenças cardiovasculares. Dados muito recentes, algumas vezes provocativos, experimentais, clínicos e epidemiológicos questionam essa associação automática mostrando que não é a quantidade, mas a distribuição de gordura que é o determinante importante. $\mathrm{O}$ acúmulo moderado de gordura abdominal pode ser mais danoso que o conseqüente sobrepeso. Tendo em vista o aumento mundial da obesidade, fatores que levam a isso em crianças e adultos jovens devem ser urgentemente identificados. Como a obesidade é uma situação cardiometabólica muito complexa, essa identificação deve ser feita em obesos não-complicados e em modelos animais adequados. A recente descoberta da transmissão inter-geração de fatores de risco da obesidade e também do papel fundamental da gestação e de eventos perinatais (fatores epi-genéticos) dão origem a conceitos e linhas de pesquisa completamente novos. Considerando a estreita relação potencial entre a microcirculação e o metabolismo tecidual, demonstrações de anormalidades estruturais e/ou funcionais na fisiologia microvascular muito cedo na vida de pessoas com risco para obesidade podem fornecer uma base sólida para investigações futuras dessas ligações. A microcirculação (arteríolas, capilares e vênulas) é conceitualmente um compartimento chave na determinação em uma ou 
várias décadas dos fatores genéticos e epi-genéticos em acúmulo de gordura. Os modelos experimentais disponíveis devem servir para responder essa questão extremamente relevante.

Palavras-chave: doença cardiovascular, diabetes mellitus, peso ao nascer, síndrome metabólica, leptina.

\section{REFERENCES}

Achard V, Desbriere R and Grino M. 2006. Perinatal programming of central obesity and the metabolic syndrome: role of glucocorticoids. Metabolic syndrome and related disorders 4: 129-137.

ADAMS K. 2006. Overweight, obesity and mortality in a large prospective cohort of persons 50 to 71 years old. N Eng J Med 355: 763-778.

Agapitov AV, Correia ML, Sinkey CA, Dopp JM AND HAYNES WG. 2002. Impaired skeletal muscle and skin microcirculatory function in human obesity. J Hypertens 20: 1401-1405.

Aloulou I, Varlet-Marie E, Mercier J and Brun JF. 2006. Hemorheological disturbances correlate with the lipid profile but not with the NCEP-ATPIII score of the metabolic syndrome. Clin Hemorheol Microcirc 35: 207-212.

Alvarez Ge, Beske SD, Ballard TP and Davy KP. 2002. Sympathetic neural activation in visceral obesity. Circulation 106: 2533-2536.

Alvarez GE, Ballard TP, Beske SD AND Davy KP. 2004. Subcutaneous obesity is not associated with sympathetic neural activation. Am J Physiol Heart Circ Physiol 287: H414-418.

Antonios TF, Rattray FM, Singer DR, MARKANDU ND, Mortimer PS AND MACGREgOR GA. 2003. Rarefaction of skin capillaries in normotensive offspring of individuals with essential hypertension. Heart 89: 175178.

Arcaro G, Zamboni M, Rossi L, Turcato E, Covi G, Armellini F, Bosello O ANd LeChi A. 1999. Body fat distribution predicts the degree of endothelial dysfunction in uncomplicated obesity. Int J Obes Relat Metab Disord 23: 936-942.

Armitage JA, TAYlor PD And Poston L. 2005. Experimental models of developmental programming: consequences of exposure to an energy rich diet during development. J Physiol 565: 3-8.

BARKER DJ. 2005. The developmental origins of insulin resistance. Horm Res 64 (Suppl 3): 2-7.
Baron AD, LAakso M, Bretchtel G, Hoit B, Watt C AND EDELMAN SV. 1990. Reduced postprandial skeletal muscle blood flow contributes to glucose intolerance in human obesity. J Clin Endocrinol Metab 70: 1525-1533.

BAyol SA, Simbi BH And STICKLAND NC. 2005. A maternal cafeteria diet during gestation and lactation promotes adiposity and impairs skeletal muscle development and metabolism in rat offspring at weaning. J Physiol 567: 951-961.

BeltowsKi J. 2006. Leptin and atherosclerosis. Atherosclerosis 189: 47-60.

BENYSHEK DC, JOHNSTON CS AND MARTIN JF. 2006. Glucose metabolism is altered in the adequatelynourished grand-offspring (F3 generation) of rats malnourished during gestation and perinatal life. Diabetologia 49: 1117-1119.

Boguszewski MC, Johannsson G, Fortes LC AND SVERrisdotTIR YB. 2004. Low birth size and final height predict high sympathetic nerve activity in adulthood. J Hypertens 22: 1157-1163.

Boullu-Ciocca S, Dutour A, Guillaume V, Achard V, Oliver C And Grino M. 2005. Postnatal diet-induced obesity in rats upregulates systemic and adipose tissue glucocorticoid metabolism during development and in adulthood: its relationship with the metabolic syndrome. Diabetes 54: 197-203.

BROOK RD, BARD RL, RUBENFIRE M, RIDKER PM AND RAJAGOPALAN S. 2001. Usefulness of visceral obesity (waist/hip ratio) in predicting vascular endothelial function in healthy overweight adults. Am J Cardiol 88: 1264 1269.

Burdette HL, Whitaker RC, Hall WC AND Daniels SR. 2006. Breastfeeding, introduction of complementary foods, and adiposity at $5 \mathrm{y}$ of age. Am J Clin Nutr 83: $550-558$.

BURKE V. 2006. Obesity in childhood and cardiovascular risk. Clin Exp Pharmacol Physiol 33: 831-837.

Byberg L, McKeigue PM, Zethelius B and Lithell HO. 2000. Birth weight and the insulin resistance syndrome: association of low birth weight with truncal obesity and raised plasminogen activator inhibitor-1 but not with abdominal obesity or plasma lipid disturbances. Diabetologia 43: 54-60.

Cettour-Rose P, SAmec S, Russell AP, SummermatTER S, Mainieri D, CARrillo-Theander C, MonTANi JP, SEYdoux J, ROHNER-JEANRENAUd F AND DulLOo AG. 2005. Redistribution of glucose from skeletal muscle to adipose tissue during catch-up fat: a link 
between catch-up growth and later metabolic syndrome. Diabetes 54: 751-756.

Cherian MA And Santoro TJ. 2006. The role of saturation of fat depots in the pathogenesis of insulin resistance. Med Hypotheses 66: 763-768.

Chin LC, Huang TY, Yu CL, Wu CH, Hsu CC and Yu HS. 1999. Increased cutaneous blood flow but impaired post-ischemic response of nutritional flow in obese children. Atherosclerosis 146: 179-185.

Cianfarani S, Germani D and Branca F. 1999. Low birthweight and adult insulin resistance: the "catch-up growth" hypothesis. Arch Dis Child Fetal Neonatal Ed 81: F71-73.

ClERK LH. 2002. Lipid infusion impairs physiologic insulin-mediated capillary recruitment and muscle glucose uptake in vivo. Diabetes 51: 1138-1145.

Clerk lH, Smith me, Rattigan S and Clark MG. 2000. Increased chylomicron triglyceride hydrolysis by connective tissue flow in perfused rat hindlimb. Implications for lipid storage. J Lipid Res 41: 329-335.

Clerk LH, Vincent MA, JAhn LA, LiU Z, Lindner JR AND BARRETT EJ. 2006. Obesity blunts insulinmediated microvascular recruitment in human forearm muscle. Diabetes 55: 1436-1442.

Clifton PM, Keogh JB, Foster PR and Noakes M. 2005. Effect of weight loss on inflammatory and endothelial markers and FMD using two low-fat diets. Int J Obes (Lond) 29: 1445-1451.

Cortinovis A, Crippa A And Ardemagni P. 1997. Hemorheology in different types of obesity. Minerva Med 88: 59-73.

Crandall DL, Quinet EM, El Ayachi S, Hreha AL, Leik CE, Savio DA, Juhan-Vague I and Alessi MC. 2006. Modulation of adipose tissue development by pharmacological inhibition of PAI-1. Arterioscler Thromb Vasc Biol 26: 2209-2215.

CURTIS JP ET AL. 2005. The obesity paradox: body mass index and outcomes in patients with heart failure. Arch Intern Med 165: 55-61.

Daly B, Scragg R, SchaAf D and Metcalf P. 2005. Low birth weight and cardiovascular risk factors in Auckland adolescents: a retrospective cohort study. N Z Med J 118: U1612.

De Jongh RT, Serne EH, IJzerman RG, De Vries G AND STEHOUWER CD. 2004a. Impaired microvascular function in obesity: implications for obesity-associated microangiopathy, hypertension, and insulin resistance. Circulation 109: 2529-2535.
De Jongh RT, Serne EH, IJzerman RG, De Vries G AND Stehouwer CD. 2004b. Free fatty acid levels modulate microvascular function: relevance for obesityassociated insulin resistance, hypertension, and microangiopathy. Diabetes 53: 2873-2882.

De Zegher F And IBAnez L. 2006. Prenatal growth restraint followed by catch-up of weight: a hyperinsulinemic pathway to polycystic ovary syndrome. Fertil Steril 86 (Suppl 1): S4-5.

DESPRES JP. 2006. Intra-abdominal obesity: an untreated risk factor for Type 2 diabetes and cardiovascular disease. J Endocrinol Invest 29: 77-82.

Despres JP, LemieuX I AND PRUD'Homme D. 2001. Treatment of obesity: need to focus on high risk abdominally obese patients. BMJ 322: 716-720.

DRAKE AJ AND WALKER BR. 2004. The intergenerational effects of fetal programming: non-genomic mechanisms for the inheritance of low birth weight and cardiovascular risk. J Endocrinol 180: 1-16.

Drake AJ, WALKER BR AND SECKL JR. 2005. Intergenerational consequences of fetal programming by in utero exposure to glucocorticoids in rats. Am J Physiol Regul Integr Comp Physiol 288: R34-38.

Dulloo AG. 2006. Regulation of fat storage via suppressed thermogenesis: a thrifty phenotype that predisposes individuals with catch-up growth to insulin resistance and obesity. Horm Res 65 (Suppl 3): 90-97.

Eriksson M, Wallander Ma, Krakau I, Wedel H AND SVARDSUDD K. 2004. Birth weight and cardiovascular risk factors in a cohort followed until 80 years of age: the study of men born in 1913. J Intern Med 255: 236-246.

Ezzahir N, Alberti C, Deghmoun S, Zaccaria I, CZernichow P, LeVy-Marchal C and JaQuet D. 2005. Time course of catch-up in adiposity influences adult anthropometry in individuals who were born small for gestational age. Pediatr Res 58: 243-247.

FAgerberg B, Bondjers L AND NiLsSon P. 2004. Low birth weight in combination with catch-up growth predicts the occurrence of the metabolic syndrome in men at late middle age: the Atherosclerosis and Insulin Resistance study. J Intern Med 256: 254-259.

Flegal KM, Graubard BI, Williamson DF and Gail MH. 2005. Excess deaths associated with underweight, overweight, and obesity. JAMA 293: 1861-1867.

Franco MC, Christofalo DM, Sawaya AL, AJzen SA AND SESSO R. 2006. Effects of low birth weight in 8- to 
13-year-old children: implications in endothelial function and uric acid levels. Hypertension 48: 45-50.

Frankel S, Elwood P, Sweetnam P, Yarnell J AND SMITH GD. 1996. Birthweight, body-mass index in middle age, and incident coronary heart disease. Lancet 348 : $1478-1480$.

FRISBEE JC. 2003. Remodeling of the skeletal muscle microcirculation increases resistance to perfusion in obese Zucker rats. Am J Physiol Heart Circ Physiol 285: H104111.

FRISBEE JC. 2005. Hypertension-independent microvascular rarefaction in the obese Zucker rat model of the metabolic syndrome. Microcirculation 12: 383-392.

FRISBEE JC. 2006. Vascular adrenergic tone and structural narrowing constrain reactive hyperemia in skeletal muscle of obese Zucker rats. Am J Physiol Heart Circ Physiol 290: H2066-2074.

Frontini MG, SRinivasan SR, Xu J and Berenson GS. 2004. Low birth weight and longitudinal trends of cardiovascular risk factor variables from childhood to adolescence: the bogalusa heart study. BMC Pediatr 4: 22.

Galland BC, Taylor BJ, Bolton DP and Sayers RM. 2006. Heart rate variability and cardiac reflexes in small for gestational age infants. J Appl Physiol 100: 933-939.

Gavin TP, Stallings 3Rd HW, Zwetsloot KA, Westerkamp LM, Ryan NA, Moore RA, Pofahl WE AND HICKNER RC. 2005. Lower capillary density but no difference in VEGF expression in obese $v$. lean young skeletal muscle in humans. J Appl Physiol 98: 315-321.

GiBBS WW. 2005. Obesity: an overblown epidemic? Sci Am 292: 70-77.

GluCKMAn PD AND Hanson MA. 2004. Living with the past: evolution, development, and patterns of disease. Science 305: 1733-1736.

Goh KL, Shore AC, Quinn M AND ToOKe JE. 2001. Impaired microvascular vasodilatory function in 3-monthold infants of low birth weight. Diabetes Care 24: 11021107.

Gomez-Ambrosi J, Salvador J, Silva C, Pastor C, Rotellar F, Gil MJ, Cienfuegos JÁ and FruhBECK G. 2006. Increased cardiovascular risk markers in obesity are associated with body adiposity: role of leptin. Thromb Haemost 95: 991-996.

Goodfellow J, Bellamy MF, Gorman St, Brownlee M, Ramsey MW, Lewis MJ, DaVies DP AND HeN-
DERSON AH. 1998. Endothelial function is impaired in fit young adults of low birth weight. Cardiovasc Res 40: 600-606.

Goodman E, Dolan LM, MorRison JA AND Daniels SR. 2005. Factor analysis of clustered cardiovascular risks in adolescence: obesity is the predominant correlate of risk among youth. Circulation 111: 1970-1977.

GRIFFITHS SL AND GRAINGER DJ. 2006. Proposal of a novel diabetogenic mechanism involving the serpin PAI1. Bioessays 28: 629-641.

Grummer-Strawn LM And Mei Z. 2004. Does breastfeeding protect against pediatric overweight? Analysis of longitudinal data from the Centers for Disease Control and Prevention Pediatric Nutrition Surveillance System. Pediatrics 113: e81-86.

Hansell J, Henareh L, Agewall S and Norman M. 2004. Non-invasive assessment of endothelial function relation between vasodilatory responses in skin microcirculation and brachial artery. Clin Physiol Funct Imaging 24: $317-322$.

Harder T, Bergman R, Kallischnigg G and PlageMANN A. 2005. Duration of breastfeeding and risk of overweight: a meta-analysis. Am J Epidemiol 162: 397 403.

Hashimoto M, Akishita M, Eto M, Kosaki K, Ako J, Sugimoto N, Yoshizumi M, Toba K And Ouchi Y. 1998. The impairment of flow-mediated vasodilatation in obese men with visceral fat accumulation. Int J Obes Relat Metab Disord 22: 477-484.

HAYden MR AND Tyagi SC. 2003. Is type 2 diabetes mellitus a vascular disease (atheroscleropathy) with hyperglycemia a late manifestation? The role of NOS, NO, and redox stress. Cardiovasc Diabetol 2: 2.

Hediger ML, Overpeck MD, Kuczmarski RJ, MCGlynn A, Maurer KR And Davis WW. 1998. Muscularity and fatness of infants and young children born small- or large-for-gestational-age. Pediatrics 102: E60.

Hermann TS, Rask-Madsen C, Ihlemannm DominGuez H, Jensen CB, Storgaard H, VaAg AA, Kober L AND Torp-Pedersen C. 2003. Normal insulin-stimulated endothelial function and impaired insulin-stimulated muscle glucose uptake in young adults with low bird weight. J Clin Endocrinol Metab 88: 1252-1257.

Hernandez GN, Dabin C and Rasia ML. 2002. Haemorheological variables in a rat model of hypertriglyceridaemic obesity and diabetes. Vet Res Commun 26: 625-635. 
Higashi Y, Sasaki S, Nakagawa K, MatsuUra H, ChaYama K AND OShima T. 2001. Effect of obesity on endothelium-dependent, nitric oxide-mediated vasodilation in normotensive individuals and patients with essential hypertension. Am J Hypertens 14: 1038-1045.

Hng TM, McLean M, Cheung NW AND Thompson CH. 2006. The interrelation of birth weight and regional lipid deposition: a twins study. Metabolism 55: 561-562.

Hoet JJ, Ozanne S And Reusens B. 2000. Influences of pre- and postnatal nutritional exposures on vascular/endocrine systems in animals. Environ Health Perspect 108 (Suppl 3): 563-568.

HofMAN PL AND CUTFIELD WS. 2006. Insulin sensitivity in people born pre-term, with low or very low birth weight and small for gestational age. J Endocrinol Invest 29: 2-8.

Holness MJ AND Sugden MC. 2006. Epigenetic regulation of metabolism in children born small for gestational age. Curr Opin Clin Nutr Metab Care 9: 482-488.

IACOBELlis G, Ribaudo MC, ZAPPATERRENo A, IANNUCCI CV AND LeONeTti F. 2005. Prevalence of uncomplicated obesity in an Italian obese population. Obes Res 13: 1116-1122.

IJZerman RG, Stehouwer CD, De Geusg EJ, van Weissenbruch MM, DelemarRe-VAN DE WAAL HA AND BOOMSMA DI. 2002. The association between low birth weight and high levels of cholesterol is not due to an increased cholesterol synthesis or absorption: analysis in twins. Pediatr Res 52: 868-872.

IJZERMAN RG, VOORDOUW JJ, VAN WEISSENBRUCH MM, Yudkin JS, Serne EH, Delemarre-van de WAAL HA AND STEhOUWER CD. 2006. TNF-alpha levels are associated with skin capillary recruitment in humans: a potential explanation for the relationship between TNF-alpha and insulin resistance. Clin Sci (Lond) 110: 361-368.

Iniguez G, Soto N, Avila A, Salazar T, Ong K, Dunger D AND MERICQ V. 2004. Adiponectin levels in the first two years of life in a prospective cohort: relations with weight gain, leptin levels and insulin sensitivity. J Clin Endocrinol Metab 89: 5500-5503.

IRVING RJ, Shore AC, BELTON NR, ELton RA, WeBB DJ AND WALKER BR. 2004. Low birth weight predicts higher blood pressure but not dermal capillary density in two populations. Hypertension 43: 610-613.

JANKE J ET AL. 2006. Adipose tissue and circulating endothelial cell specific molecule-1 in human obesity. Horm Metab Res 38: 28-33.

Jiang X, SRINIVASAN SR, URbina E ANd Berenson GS.
1995. Hyperdynamic circulation and cardiovascular risk in children and adolescents. The Bogalusa Heart Study. Circulation 91: 1101-1106.

Jimenez-Chillaron JC, Hernandez-VALENCIA M, Lightner A, Faucette RR, Reamer C, Przybyla R, Ruest S, BARry K, OtIS JP AND PATti ME. 2006. Reductions in caloric intake and early postnatal growth prevent glucose intolerance and obesity associated with low birthweight. Diabetologia 49: 1974-1984.

JONES SE AND NYENGAARD JR. 1998. Low birth weight and cardiovascular disease: myth or reality? Curr Opin Lipidol 9: 309-312.

Jonsson S, Hedblad B, Engstrom G, Nilsson P, BERGLUND S AND JANZON L. 2002. Influence of obesity on cardiovascular risk. Twenty-three-year follow-up of 22,025 men from an urban Swedish population. Int J Obes Relat Metab Disord 26: 1046-1053.

Kalies H, Heinrich J, Borte N, SchaAf B, Von Berg A, von Kries R, Wichmann He and Bolte G. 2005. The effect of breastfeeding on weight gain in infants: results of a birth cohort study. Eur J Med Res 10: 36-42.

KAYES SK AND HindMARSH PC. 2006. Catch-up growth: an overview. Pediatr Endocrinol Rev 3: 365-378.

Kemppainen J, Tsuchida H, Stolen K, Karlsson H, BJornholm M, Heinonen OJ, NuUtil P, Krook A, KNUUTI J AND ZIERATH JR. 2003. Insulin signalling and resistance in patients with chronic heart failure. $\mathrm{J}$ Physiol 550: 305-315.

Kern PA, Simsolo RB And Fournier M. 1999. Effect of weight loss on muscle fibre type, fibre size, capillarity, and succinate dehydrogenase activity in humans. J Clin Encocrinol Metab 84: 4185-4190.

Khan F, Green FC, Forsyth JS, Greene SA, MorRISS AD AND BELCH JJ. 2003. Impaired microvascular function in normal children: effects of adiposity and poor glucose handling. J Physiol 551: 705-711.

Khan IY, Dekou V, Douglas G, Jensen R, Hanson MA, Poston L AND TAYLOR PD. 2005. A high-fat diet during rat pregnancy or suckling induces cardiovascular dysfunction in adult offspring. Am J Physiol Regul Integr Comp Physiol 288: R127-133.

Kim C, Park J, Kang E, Ahn C, Cha B, Lim S, Kim K AND LEE H. 2006. Comparison of body fat composition and serum adiponectin levels in diabetic obesity and nondiabetic obesity. Obesity (Silver Spring) 14: 1164-1171.

Kindig CA, Musch TI, Basaraba RJ And Poole DC. 
1999. Impaired capillary hemodynamics in skeletal muscle of rats in chronic heart failure. J Appl Physiol 87: $652-660$.

KinRA S, BAumer JH AND Davey Smith G. 2005. Early growth and childhood obesity: a historical cohort study. Arch Dis Child 90: 1122-1127.

Kip Ke, Marroquin OC, Kelley De, Johnson BD, Kelsey SF, Shaw LJ, Rogers WJ and Reis SE. 2004. Clinical importance of obesity versus the metabolic syndrome in cardiovascular risk in women: a report from the Women's Ischemia Syndrome Evaluation (WISE) study. Circulation 109: 706-713.

KNudson JD, Dincer UD, Zhang C, SWAFFord JR AN, Koshida R, PICCHI A, Focardi M, Dick GM AND TUNE JD. 2005. Leptin receptors are expressed in coronary arteries, and hyperleptinemia causes significant coronary endothelial dysfunction. Am J Physiol Heart Circ Physiol 289: H48-56.

Konstantinides S, Schafer K, Koschnick S AND LOSKUTOFF DJ. 2001. Leptin-dependent platelet aggregation and arterial thrombosis suggests a mechanism for atherothrombotic disease in obesity. J Clin Invest 108: $1533-1540$.

Kriketos AD, Pan DA, Lillioja S, Cooney GJ, Baur LA, Milner Mr, Sutton JR, Jenkins AB, Bogardus C AND STOLIEN LH. 1996. Interrelationships between muscle morphology, insulin action, and adiposity. Am J Physiol 270: R1332-1339.

Law CM, Shiell AW, Newsome CA, Sydall He, Shinebourne EA, FAYERs PM, MARTYN CN AND DE SWIET M. 2002. Fetal, infant, and childhood growth and adult blood pressure: a longitudinal study from birth to 22 years of age. Circulation 105: 1088-1092.

Lecklin A, Dube MG, Torto RN, Kalra PS AND KALRA SP. 2005. Perigestational suppression of weight gain with central leptin gene therapy results in lower weight F1 generation. Peptides 26: 1176-1187.

LeEson CP, Kattenhorn M, Morley R, LuCAS A AND DEANFIELDD JE. 2001a. Impact of low birth weight and cardiovascular risk factors on endothelial function in early adult life. Circulation 103: 1264-1268.

LeEson CP, Kattenhorn M, DeAnField JE ANd LuCAS A. 2001b. Duration of breast feeding and arterial distensibility in early adult life: population based study. British Med J 322: 643-647.

Levitt NS, Lambert EV, Woods D, Hales CN, ANDREW R AND SECKL JR. 2000. Impaired glucose tolerance and elevated blood pressure in low birth weight, nonobese, young south african adults: early programming of cortisol axis. J Clin Endocrinol Metab 85: 4611-4618.

Levy-Marchal C And Czernikow P. 2006. Small for gestational age and the metabolic syndrome: which mechanism is suggested by epidemiological and clinical studies? Horm Res 65 (Suppl 3): 123-130.

Lillioja S, Young AA, Culter CL, Ivy JL, ABbott WG, ZaWAdZKi JK, YKI-JARVINEN H, Christin L, Secomb TW AND Bogardus C. 1987. Skeletal muscle capillary density and fibre type are possible determinants of in vivo insulin resistance in man. J Clin Invest 80: $415-424$.

Lind L, HALL J AND JOHANSSON K. 2002. Evaluation of four different methods to measure endothelium-dependent vasodilation in the human peripheral circulation. Clin Sci (Lond) 102: 561-567.

Louey S And Thornburg KL. 2005. The prenatal environment and later cardiovascular disease. Early Hum Dev 81: 745-751.

Louey S, Cock ML and Harding R. 2005. Long term consequences of low birthweight on postnatal growth, adiposity and brain weight at maturity in sheep. J Reprod Dev 51: 59-68.

LUCAS A. 1998. Programming by early nutrition: an experimental approach. J Nutr 128: 401S-406S.

MA LJ ET AL. 2004. Prevention of obesity and insulin resistance in mice lacking plasminogen activator inhibitor 1 . Diabetes 53: 336-346.

Maeda N, Cicha I, Tateishi N And Suzuki Y. 2006. Triglyceride in plasma: prospective effects on microcirculatory functions. Clin Hemorheol Microcirc 34: 341-346.

Malenfant P, JoAnisse DR, Theriault R, GoodPaster BH, Kelley DE ANd Simoneau JA. 2001. Fat content in individual muscle fibres of lean and obese subjects. Int J Obes Relat Metab Disord 25: 1316-1321.

MARIN P, ANDERSSON B, KROTKIEWSKi M AND BJoRNTORP P. 1994. Muscle fiber composition and capillary density in women and men with NIDDM. Diabetes Care 17: $382-386$.

Mark AL, Correia ML, Rahmouni K and Haynes WG. 2004. Loss of leptin actions in obesity: two concepts with cardiovascular implications. Clin Exp Hypertens 26: 629-636.

Martin H, Hu J, Gennser G And Norman M. 2000a. Impaired endothelial function and increased carotid stiffness in 9-year-old children with low birthweight. Circulation 102: 2739-2744. 
Martin H, Gazelius B And Norman M. 2000b. Impaired acetylcholine-induced vascular relaxation in low birth weight infants: implications for adult hypertension? Pediatr Res 47: 457-462.

Martinez-Cordero C, AMADOR-LiconA N, GuizarMendoza JM, HeRnandez-Mendez J And RueLAS-OROZCO G. 2006. Body fat at birth and cord blood levels of insulin, adiponectin, leptin, and insulin-like growth factor-I in small-for-gestational-age infants. Arch Med Res 37: 490-494.

Massiera F, Saint-Marc P, Seydoux J, Murata T, Kobayashi T, Narumiya S, Guesnet P, Amri EZ, Negrel RA AND Aillhaud G. 2003. Arachidonic acid and prostacyclin signaling promote adipose tissue development: a human health concern? J Lipid Res 44: 271279.

Mather KJ, Lteif A, Steinberg ho and Baron AD 2004. Interactions between endothelin and nitric oxide in the regulation of vascular tone in obesity and diabetes. Diabetes 53: 2060-2066.

Matsumoto Y, Ohno H, Noguchi I, KikUchi Y AND KURIHARA T. 2006. Disturbance of microcirculation due to unhealthy lifestyle: Cause of type 2 diabetes. Med Hypotheses 66: 550-553.

MCAllister AS, AtKinson AB, Johnston GD AND MCCANCEC DR. 1999. Relationship of endothelial function to birth weight in humans. Diabetes Care 22: 20612066.

MCCANCEC RA. 1962. Food, growth, and time. Lancet 2: 671-676.

McCarron P, Davey Smith G and Hattersley AT. 2004. Type 2 diabetes in grandparents and birth weight in offspring and grandchildren in the ALSPAC study. J Epidemiol Community Health 58: 517-522.

MericQ V. 2006. Prematurity and insulin sensitivity. Horm Res 65 (Suppl 3): 131-136.

Mericg V, Ong KK, Bazaes R, Pena V, Avila A, Salazar T, Soto N, Iniguez G and Dunger DB. 2005. Longitudinal changes in insulin sensitivity and secretion from birth to age three years in small- and appropriate-for-gestational-age children. Diabetologia 48: 2609 2614.

Minson CT AND Wong BJ. 2004. Reactive hyperemia as a test of endothelial or microvascular function? J Am Coll Cardiol 43: 2147; author reply 2147-2148.

Mitchell GF, Vita JA, Larson MG, Parise H, Keyes MJ, WARNER E, VASAN RS, LEVy D AND BENJAMIN EJ. 2005. Cross-sectional relations of peripheral micro- vascular function, cardiovascular disease risk factors, and aortic stiffness: the Framingham Heart Study. Circulation 112: 3722-3728.

Moan A, Nordby G, Os I, Birkeland KI and KJeldSEN SE. 1994. Relationship between hemorrheologic factors and insulin sensitivity in healthy young men. Metabolism 43: 423-427.

Modi N, Thomas EL, Harrington tA, Uthaya S, Dore CJ AND BELL JD. 2006. Determinants of adiposity during preweaning postnatal growth in appropriately grown and growth-restricted term infants. Pediatr Res 60 : 345-348.

Mori Y, Hoshino K, YoKota K, ITOH Y AND TAJima N. 2006. Differences in the pathology of the metabolic syndrome with or without visceral fat accumulation: a study in pre-diabetic Japanese middle-aged men. Endocrine 29: 149-153.

Morris MJ, Velkoska E and Cole TJ. 2005. Central and peripheral contributions to obesity-associated hypertension: impact of early overnourishment. Exp Physiol 90: 697-702.

Mozes S, Sefcikova Z, Lenhardt L and Racek L. 2004. Obesity and changes of alkaline phosphatase activity in the small intestine of 40- and 80-day-old rats subjected to early postnatal overfeeding or monosodium glutamate. Physiol Rev 53: 177-186.

Nelson MC, Gordon-Larsen P ANd AdAIR LS. 2005. Are adolescents who were breast-fed less likely to be overweight? Analyses of sibling pairs to reduce confounding. Epidemiology 16: 247-253.

Nestel PJ, Yamashita T, Sasahara T, Chin-Dusting JP, ESLER MD, DART AM AND Jennings GL. 1998. Control of the forearm microcirculation: interactions with measures of obesity and noradrenaline kinetics. Clin Sci (Lond) 95: 203-212.

Newsome CA, Shiell AW, Fall CH, Phillips DI, SHIER R AND LAW CM. 2003. Is birth weight related to later glucose and insulin metabolism? - A systematic review. Diabet Med 20: 339-348.

Nielsen S, Halliwill JR, Joyner MJ and Jensen MD. 2004. Vascular response to angiotensin II in upper body obesity. Hypertension 44: 435-441.

Nilsson PM, Ostergren PO, Nyberg P, Soderström M AND ALLEBECK P. 1997. Low birth weight is associated with elevated systolic blood pressure in adolescence: a prospective study of a birth cohort of 149378 Swedish boys. J Hypertens 15: 1627-1631.

Norman M And Martin H. 2003. Preterm birth attenu- 
ates association between low birth weight and endothelial dysfunction. Circulation 108: 996-1001.

Nusz DJ, White DC, Dai Q, Pippen AM, Thompson MA, Walton GB, Parsa CJ, Koch WJ and Annex BH. 2003. Vascular rarefaction in peripheral skeletal muscle after experimental heart failure. Am J Physiol Heart Circ Physiol 285: H1554-1562.

Oddy WH, SCOTt JA, GRAHAM KI AND Binns CW. 2006. Breastfeeding influences on growth and health at one year of age. Breastfeed Rev 14: 15-23.

ONG KK. 2006. Size at birth, postnatal growth and risk of obesity. Horm Res 65 (Suppl 3): 65-69.

Oren A, Vos LE, UiterwaAl CS, Gorissen WH, GrobBeE DE AND Bots ML. 2004. Birth weight and carotid intima-media thickness: new perspectives from the atherosclerosis risk in young adults (ARYA) study. Ann Epidemiol 14: 8-16.

ORSHAL JM AND KHALIL RA. 2004. Interleukin-6 impairs endothelium-dependent NO-cGMP-mediated relaxation and enhances contraction in systemic vessels of pregnant rats. Am J Physiol Regul Integr Comp Physiol 286: R1013-1023.

Ouchi N, Shibata R and Walsh K. 2006. Cardioprotection by adiponectin. Trends Cardiovasc Med 16: 141-146.

OWen CG, MARTin RM, Whincup PH, SMith GD AND CooK DG. 2005. Effect of infant feeding on the risk of obesity across the life course: a quantitative review of published evidence. Pediatrics 115: 1367-1377.

Ozanne SE And Hales NC. 2005. Poor fetal growth followed by rapid postnatal catch-up growth leads to premature death. Mech Ageing Dev 126: 852-854.

PAJUNEN P ET AL. 2005. Five-year risk of developing clinical diabetes after first myocardial infarction; the FINAMI study. Diabet Med 22: 1334-1337.

Palatini P, Vriz O, Nesbitt S, Amerena J, Majahalme S, Valentini M and Julius S. 1999. Parental hyperdynamic circulation predicts insulin resistance in offspring: The Tecumseh Offspring Study. Hypertension 33: 769-774.

Pasimeni G, Ribaudo MC, Capoccia D, Rossi F, Bertone C, Leonetti F And Santiemma V. 2006. Non-invasive evaluation of endothelial dysfunction in uncomplicated obesity: relationship with insulin resistance. Microvasc Res 71: 115-120.

Pietilainen KH, Bergholm R, Rissanen A, Kaprio J, HAKKINEN AM, SATTAR N AND YKI-JARVINEN H. 2006. Effects of acquired obesity on endothelial function in monozygotic twins. Obesity (Silver Spring) 14: 826837.
Pladys P ET AL. 2005. Microvascular rarefaction and decreased angiogenesis in rats with fetal programming of hypertension associated with exposure to a low-protein diet in utero. Am J Physiol Regul Integr Comp Physiol 289: R1580-1588.

Plagemann A. 2006. Perinatal nutrition and hormonedependent programming of food intake. Horm Res 65 (Suppl 3): 83-89.

Plagemann A ANd Harder T. 2005. Breast feeding and the risk of obesity and related metabolic diseases in the child. Metabolic syndrome and related disorders 3: 222232.

Plagemann A, Heidrich I, Gotz F, Rohde W And DORNER G. 1992. Obesity and enhanced diabetes and cardiovascular risk in adult rats due to early postnatal overfeeding. Exp Clin Endocrinol 99: 154-158.

Pohl U, De Wit C and Gloe T. 2000. Large arterioles in the control of blood flow: role of endothelium-dependent dilation. Acta Physiol Scand 168: 505-510.

POPKIN BM. 2004. The nutrition transition: an overview of world patterns of change. Nutr Rev 62: S140-143.

RAHMOUNI K AND HAYNES WG. 2005. Endothelial effects of leptin: implications in health and diseases. Curr Diab Rep 5: 260-266.

Ramadhani MK, Grobbee De, Bots ML, Castro Cabezas M, Vos Le, Oren a and UiterwaAl CS. 2006. Lower birth weight predicts metabolic syndrome in young adults: the Atherosclerosis Risk in Young Adults (ARYA)-study. Atherosclerosis 184: 21-27.

RAYMond SU, LEeder S AND GREenberg HM. 2006. Obesity and cardiovascular disease in developing countries: a growing problem and an economic threat. Curr Opin Clin Nutr Metab Care 9: 111-116.

Remacle C, Bieswal F and Reusens B. 2004. Programming of obesity and cardiovascular disease. Int $\mathrm{J}$ Obes Relat Metab Disord 28 (Suppl 3): S46-53.

REN J. 2004. Leptin and hyperleptinemia - from friend to foe for cardiovascular function. J Endocrinol 181: 1-10.

Romero-Corral A, MONTORI VM, SOMERs VK, KorineK J, THOMAS RJ, AlLison TG, MOOKADAM F AND LoPEZ-Jimenez F. 2006. Association of bodyweight with total mortality and with cardiovascular events in coronary artery disease: a systematic review of cohort studies. Lancet 368: 666-678.

Schmidt I, Fritz A, Scholch C, Schneider D, Simon E And Plagemann A. 2001. The effect of leptin treatment on the development of obesity in overfed suckling Wistar rats. Int J Obes Relat Metab Disord 25: 11681174. 
Schwitter J, Oelhafen M, Wyss BM, Kozerke S, Amann-Vesti B, Luscher TF AND Borsiger P. 2006. 2D-spatially-selective real-time magnetic resonance imaging for the assessment of microvascular function and its relation to the cardiovascular risk profile. J Cardiovasc Magn Reson 8: 759-769.

Selling KE, CARstensen J, Finnstrom O ANd Sydsjo G. 2006. Intergenerational effects of preterm birth and reduced intrauterine growth: a population-based study of Swedish mother-offspring pairs. BJGO 113: 430-440.

Serne EH, Stehouwer CD, Ter Maaten JC, Ter Wee PM, DONKER AJ AND GANS RO. 2000. Birth weight relates to blood pressure and microvascular function in normal subjects. J Hypertens 18: 1421-1427.

Seywert AJ, Kubli S, Giusti V, Feihl F, Waeber B AND TAPPY L. 2004. Similarity of cutaneous reactive hyperemia in the forearm of women with and without hyperinsulinemia. Int J Obes Relat Metab Disord 28: 611615.

Shamim-Uzzaman QA, Pfenninger D, Kehrer C, Chakrabarti A, Kacirotti N, Rubenfire M, BROOK R AND RAJAGOPALAN S. 2002. Altered cutaneous microvascular responses to reactive hyperaemia in coronary artery disease: a comparative study with conduit vessel responses. Clin Sci (Lond) 103: 267-273.

SHIMOMURA I ET AL. 1996. Enhanced expression of PAI-1 in visceral fat: possible contributor to vascular disease in obesity. Nat Med 2: 800-803.

Silber HA, Ouyang P, Bluemke DA, Gupta SN, Foo TK AND LimA JA. 2005. Why is flow-mediated dilation dependent on arterial size? Assessment of the shear stimulus using phase-contrast magnetic resonance imaging. Am J Physiol Heart Circ Physiol 288: H822-828.

Simmons RA, Templeton LJ And Gertz SJ. 2001. Intrauterine growth retardation leads to the development of type 2 diabetes in the rat. Diabetes 50: 2279-2286.

SingHAL A. 2005. Endothelial dysfunction: role in obesityrelated disorders and the early origins of CVD. Proc Nutr Soc 64: $15-22$.

Singhal A. 2006. Early nutrition and long-term cardiovascular health. Nutr Rev 64: S44-49; discussion S72-91.

Singhal A, Faroogi IS, O'Rahilly S, Cole TJ, FeWTRELL M AND LUCAS A. 2002. Early nutrition and leptin concentrations in later life. Am J Clin Nutr 75: 993-999.

Singhal A, Cole tJ, Fewtrell M, Deanfield J and LUCAS A. 2004. Is slower early growth beneficial for long-term cardiovascular health? Circulation 109: 11081113.
SJostand M, GudbJornsdottir S, STRINDBERG L AND LONNROTH P. 2005. Delayed transcapillary delivery of insulin to muscle interstitial fluid after oral glucose load in obese subjects. Diabetes 54: 152-157.

Smith GD, Sterne J, Tynelius P, Lawlor DA AND RASMUSSEN F. 2005. Birth weight of offspring and subsequent cardiovascular mortality of the parents. Epidemiology 16: 563-569.

Soto N, Bazaes RA, Pena V, Salazar T, Avila A, Iniguez G, ONG KK, Dunger DB AND MERICQ MV. 2003. Insulin sensitivity and secretion are related to catchup growth in small-for-gestational-age infants at age 1 year: results from a prospective cohort. J Clin Endocrinol Metab 88: 3645-3650.

STEPP DW. 2006. Impact of obesity and insulin resistance on vasomotor tone: nitric oxide and beyond. Clin Exp Pharmacol Physiol 33: 407-414.

Stern MP, Morales PA, HafFner SM And VAldeZ RA. 1992. Hyperdynamic circulation and the insulin resistance syndrome ("syndrome X"). Hypertension 20 : 802-808.

Stettler N, Stallings VA, Troxel AB, Zhao J, Schinnar R, Nelson SE, Ziegler EE and Strom BL. 2005. Weight gain in the first week of life and overweight in adulthood: a cohort study of European American subjects fed infant formula. Circulation 111: 1897-1903.

Stocker CJ, ARCh JR ANd CAWthorne MA. 2005. Fetal origins of insulin resistance and obesity. Proc Nutr Soc 64: 143-151.

St-Pierre P, Bouffard L, PAPIRAKis ME and Maheux P. 2006. Increased extravasation of macromolecules in skeletal muscles of the Zucker rat model. Obesity (Silver Spring) 14: 787-793.

Suh HS, Park YW, Kang JH, Lee SH, Lee HS And SHIM KW. 2005. Vascular endothelial dysfunction tested by blunted response to endothelium-dependent vasodilation by salbutamol and its related factors in uncomplicated pre-menopausal obese women. Int J Obes (Lond) 29: $217-222$.

Tigno XT, Selaru IK, Angeloni SV and Hansen BC. 2003. Is microvascular flow rate related to ghrelin, leptin and adiponectin levels? Clin Hemorheol Microcirc 29: 409-416.

TOOKE JE AND GoH KL. 1998. Endotheliopathy precedes type 2 diabetes. Diabetes Care 21: 2047-2049.

Tudor A, Musat A, Bari M, Peta D ANd Cochior D. 2005. Observations on peripheral microcirculation in 
young hypertensive patients. Rom J Intern Med 43: 7378.

Tuya C, Mutch WJ, Broom I, Campbell DM and MCNEILL G. 2003. Size at birth, fasting glucose and insulin levels and insulin resistance in adult twins. Twin Res 6: 302-306.

Vaag A, Jensen CB, Poulsen P, Brons C, Pilgaard K, Grunnet L, Vielwerth S and Alibegovic A. 2006. Metabolic aspects of insulin resistance in individuals born small for gestational age. Horm Res 65 (Suppl 3): 137-143.

Valle M, Martos R, Gascon F, CANete R, ZaFra MA AND Morales R. 2005. Low-grade systemic inflammation, hypoadiponectinemia and a high concentration of leptin are present in very young obese children, and correlate with metabolic syndrome. Diabetes Metab 31: 55-62.

VAN Guilder GP, Hoetzer GL, Dengel DR, StAufFer BL AND DeSouzA CA. 2006. Impaired endotheliumdependent vasodilation in normotensive and normoglycemic obese adult humans. J Cardiovasc Pharmacol 47: 310-313.

VeEning MA, VAN Weissenbruch MM and DeleMARRE-VAN DE WAAL HA. 2002. Glucose tolerance, insulin sensitivity, and insulin secretion in children born small for gestational age. J Clin Endocrinol Metab 87: 4657-4661.

VeEning MA, VAN Weissenbruch MM AND DeleMARRE-VAN DE WAAL HA. 2004. Sequelae of syndrome $\mathrm{X}$ in children born small for gestational age. Horm Res 61: 103-107.

Vickers MH, Gluckman PD, COVEny AH, Hofman PL, Cutfield WS, Gertler A, Breier BH AND HARRIS M. 2005. Neonatal leptin treatment reverses developmental programming. Endocrinology 146: 42114216.

Vigili de Kreutzenberg S, Kiwanuka E, Tiengo A AND Avogaro A. 2003. Visceral obesity is characterized by impaired nitric oxide-independent vasodilation. Eur Heart J 24: 1210-1215.

Villela NR, Kraemer de Aguiar LG, Bahia LR, Bottino DA And Bouskela E. 2006. Does endothelial dysfunction correlate better with waist-to-hip ratio than with body mass index or waist circumference among obese patients? Clinics 61: 53-58.

Wannamethee SG, Tchernova J, Whincup P, Lowe GD, Kelly A, Rumley A, Wallace AM and SatTAR N. 2006. Plasma leptin: Associations with metabolic, inflammatory and haemostatic risk factors for cardiovascular disease. Atherosclerosis 191: 418-426.

WAScher TC, WOLKart G, Russell JC AND BRUNNER F. 2000. Delayed insulin transport across endothelium in insulin-resistant JCR:LA-cp rats. Diabetes 49: 803-809.

Weinbrenner T, Schroder H, Escurriol V, Fito M, Elosua R, Vila J, Marrugat J and Covas MI. 2006. Circulating oxidized LDL is associated with increased waist circumference independent of body mass index in men and women. Am J Clin Nutr 83: 30-35; quiz 181-182.

Westerbacka J, VehkaVaARa S, Bergholm R, WilKINSON I, COCKCROFT J AND YKI-JARVINEN H. 1999. Marked resistance of the ability of insulin to decrease arterial stiffness characterizes human obesity. Diabetes 48 : $821-827$.

WIERNSPERGER N. 2000. Defects in microvascular haemodynamics during prediabetes: contributor or epiphenomenon? Diabetologia 43: 1439-1448.

Wiernsperger N, Nivoit P AND Bouskela E. 2006. Obstructive sleep apnea and insulin resistance: a role for microcirculation? Clinics 61: 253-266.

Wiernsperger N, Nivoit P, Kraemer de Aguiar LG AND BOUSKELA E. 2007. Microcirculation and the metabolic syndrome. Microcirculation 14: 403-438.

Wildman RP, Mackey RH, Bostom A, Thompson T AND SutTon-TyrRell K. 2003. Measures of obesity are associated with vascular stiffness in young and older adults. Hypertension 42: 468-473.

Wong BJ, Wilkins BW, Holowatz LA And Minson CT. 2003. Nitric oxide synthase inhibition does not alter the reactive hyperemic response in the cutaneous circulation. J Appl Physiol 95: 504-510.

YEUNG MY. 2006. Postnatal growth, neurodevelopment and altered adiposity after preterm birth - from a clinical nutrition perspective. Acta Paediatr 95: 909-917.

Youd JM, Rattigan S AND Clark MG. 2000. Acute impairment of insulin-mediated capillary recruitment and glucose uptake in rat skeletal muscle in vivo by TNF-alpha. Diabetes 49: 1904-1909.

YUdKIN JS, KumARI M, HUMPhries SE AND MOHAMEDALI V. 2000. Inflammation, obesity, stress and coronary heart disease: is interleukin-6 the link? Atherosclerosis 148: 209-214.

YUdKIN JS, ERINGA E AND STEHOUWER CD. 2005. "Vasocrine" signalling from perivascular fat: a mechanism linking insulin resistance to vascular disease. Lancet 365: $1817-1820$. 
YURA S ET AL. 2005. Role of premature leptin surge in obesity resulting from intrauterine undernutrition. Cell Metab 1: 371-378.
Zhu W, Li M, Huang X And Neubauer H. 2005. Association of hyperviscosity and subclinical atherosclerosis in obese schoolchildren. Eur J Pediatr 164: 639-645. 